\title{
Secretion of matrix metalloproteinases 2 and 9 and tissue inhibitor of metalloproteinases into follicular fluid during follicle development in equine ovaries
}

\author{
S. C. Riley ${ }^{1,3}$, A. H. Gibson², R. Leask ${ }^{1}$, D. J. W. Mauchline ${ }^{1}$, \\ H. G. Pedersen ${ }^{2}$ and E. D. Watson ${ }^{2}$ \\ ${ }^{1}$ Obstetrics and Gynaecology Section, Department of Reproductive and Developmental \\ Sciences and ${ }^{2}$ Department of Veterinary Clinical Studies, University of Edinburgh, \\ Edinburgh, UK; and ${ }^{3}$ Obstetrics and Gynaecology, Centre for Reproductive Biology, \\ University of Edinburgh, 37 Chalmers Street, Edinburgh EH3 9ET, UK
}

Extensive tissue remodelling is required in equine ovaries for follicle growth and development and also migration of the follicle to the ovulatory fossa, where ovulation occurs. The mechanisms for these processes are largely unexplored. Matrix metalloproteinases (MMPs) and their endogenous tissue inhibitors (TIMPs) are important for control of breakdown of extracellular matrix during tissue remodelling. The aims of this study were to determine the pattern and sites of secretion of the gelatinases MMP-2 and -9 and TIMPs into follicular fluid during follicle development in mare ovaries. The predominant gelatinase detected in follicular fluid was MMP-2, which was present in similar amounts throughout follicular development, as demonstrated by zymography. MMP-9 was also present in follicular fluid and secretion increased significantly $(P<0.05)$ with development of follicles from $<10 \mathrm{~mm}$ to $11-20 \mathrm{~mm}$ in diameter. Follicular fluid also contained TIMP-1, TIMP2, unglycosylated and glycosylated TIMP-3, and TIMP-4, as shown by reverse zymography. The abundance of TIMPs remained largely unchanged during follicle development. MMP-2 and -9 were localized by immunohistochemistry to stromal cells and granulosa and theca cells. TIMP-1, -2, -3 and -4 were present in granulosa and theca cells of the follicle and in stromal cells and also associated with extracellular matrix of the ovarian stromal tissue. The MMPs and TIMPs are likely to be involved in the regulation of the breakdown of extracellular matrix during tissue remodelling for follicle development and migration to the ovulation fossa in mares.

\section{Introduction}

The unique structure of the equine ovary, the large eventual size of the preovulatory follicle (sometimes to $>50 \mathrm{~mm}$ in diameter), and its migration to the ovulation fossa and subsequent ovulation (Ginther, 1992) require profound tissue remodelling. The processes of development and particularly migration have been largely open to speculative theories suggesting that the large size of the ovulatory follicle results in pressure that forces it along the line of least resistance to the fossa, or by changes in the extracellular matrix that produce a line of least resistance along which migration can take place (Harrison, 1946; Prickett, 1966). The process of migration can be visualized by transrectal ultrasonography. Approximately $85 \%$ of preovulatory follicles undergo a profound change in shape from spherical to pear-shaped or conical, pointing towards the ovulatory fossa, coincident with a decrease in follicle turgidity (Pierson and Ginther, 1985). Ovulation is likely to occur

Email: Simon.C.Riley@ed.ac.uk due to controlled focal weakening of the follicular wall caused by apoptosis rather than an increase in intrafollicular pressure (Murdoch, 1995). A tear is visualized by ultrasonography in the follicle wall before ovulation, which is thought to be due to breakdown of ovarian stroma (Carnevale et al., 1988). Morphological examination has demonstrated that rupture of the deep layers of ovarian connective tissue is evident in conjunction with disruption of the surface cuboidal and columnar cells of the ovulation fossa (Witherspoon and Talbot, 1970). However, little is known about the breakdown of extracellular matrix during these processes or the enzymes involved in these remodelling events.

The matrix metalloproteinases (MMPs) are a family of key enzymes involved in degradation of extracellular matrix during tissue remodelling. MMPs possess a broad range of substrate specificities, with the capability of breaking down most extracellular matrix components, including all forms of collagen. MMPs are secreted into the extracellular environment as an inactive pro-form and activity requires cleavage of the pro- domain resulting in a conformational change revealing the active site. The MMPs are regulated by 
a family of specific endogenous inhibitors that currently has four members: the tissue inhibitors of matrix metalloproteinases (TIMPs; Woessner, 1991; Hulboy et al., 1997). TIMPs are also secreted by many cell types and bind in a ratio of 1:1 to form non-covalent complexes with a broad specificity to MMPs, thus inhibiting their enzymatic function and regulating remodelling of extracellular matrix.

Members of the MMP and TIMP families are expressed in the ovaries of mice (Hagglund et al., 1999), rats (Bagavandoss, 1998), sheep (Murdoch and McCormick, 1992), cows (Smith et al., 1996) and humans (Duncan et al., 1998; for a review of MMPs in ovarian function see Mclntush and Smith, 1998). Song et al. (1999) demonstrated that the gelatinases MMP-2 (gelatinase A, 72 kDa type IV collagenase) and MMP-9 (gelatinase B, 92 kDa type IV collagenase) are secreted in vitro by stromal cells of equine ovaries. The gelatinases primarily degrade type IV collagen, which is a major constituent of basement membranes. TIMP-1, -2 and -3 are also secreted by equine ovarian stromal cells. However, little is known about the regulation of MMPs and TIMPs in equine ovaries in vivo.

The aims of the present study were to examine the secretion of the gelatinases MMP-2, MMP-9 and the TIMPs into follicular fluid during follicle development and to investigate their likely sites of cellular secretion.

\section{Materials and Methods}

\section{Collection and preparation of tissue and follicular fluid samples}

Ovaries from mature cyclic mares were collected at post mortem or by ovariectomy. The ovariectomy was performed via a colpotomy incision after appropriate sedation and analgesia, as described by Watson and Sertich (1990). Follicles were identified, their diameters were recorded and follicular fluid was collected by needle aspiration.

Follicular wall coloration and morphology of granulosa cells recovered by curettage of the follicular wall were evaluated and oestradiol concentrations in follicular fluid were measured to distinguish follicles as healthy or atretic. The presence or absence of granulosa cell apoptosis was detected after examination for laddering of DNA and staining with ethidium bromide (Pedersen et al., 2000). Validation of the methods used to classify follicles as healthy or atretic was achieved by retrospective histological analysis of 34 follicles 3-54 mm in diameter (Pedersen, 2000).

Follicular fluid samples from healthy growing follicles were selected from four stages of development determined by the follicle diameters: < $10 \mathrm{~mm}, 11-20 \mathrm{~mm}, 21-30 \mathrm{~mm}$ and 30-45 mm (mares in oestrus) ( $n=2$ mares per group). Fluid samples were also collected from atretic follicles with the same criteria for sizes $\leqslant 30 \mathrm{~mm}$ in diameter. Furthermore, two samples of fluid were collected from granulosa cell tumours. All follicular fluid samples were dialysed (7.5 kDa molecular mass cut-off; Tube-O-Dialyser, Chemicon
International Ltd, Harrow) for $17 \mathrm{~h}$ at $23^{\circ} \mathrm{C}$ against water, which also removes small ions that can disrupt electrophoresis, and the samples were then stored at $-20^{\circ} \mathrm{C}$ before analysis. Sections of healthy growing follicular wall tissue and underlying ovarian tissue (approximately $7 \mathrm{~mm}^{3}$ ) were collected and fixed in 10\% (v/v) neutral buffered formalin for $24 \mathrm{~h}$, washed in $70 \%(\mathrm{v} / \mathrm{v})$ alcohol and embedded in paraffin wax.

\section{Radioimmunoassay for oestradiol}

Concentrations of oestradiol were measured directly in follicular fluid without extraction. Fluid was diluted in assay buffer from 1:100 to 1:10 000. The assay was performed as described by Glasier et al. (1989). Assay sensitivity was 8 pg $\mathrm{ml}^{-1}$ and intra- and interassay coefficients of variation were 4.6 and $7.8 \%$, respectively. Displacement curves produced by serial dilutions of follicular fluid and spiking of samples were parallel to the standard curve.

\section{Identification and measurement of MMP-2 and MMP-9 by zymography}

Activity of gelatinases (MMP-2 and MMP-9) in follicular fluid was detected using zymography as described by Rawdanowicz et al. (1994) with minor modifications (Riley et al., 1999a). Follicular fluid samples and fluids from atretic follicles (1.0-7.5 $\mu \mathrm{l}$; optimal volume established as $1.5 \mu \mathrm{l}$ ) were separated by SDS-PAGE (7.5\% (w/v) gels; Minigel apparatus; Bio-Rad, Hemel Hempstead) using gels containing gelatin $\left(1 \mathrm{mg} \mathrm{ml}^{-1}\right)$ in non-reducing conditions. Gels were washed in 2.5\% (v/v) Triton X-100 and incubated in

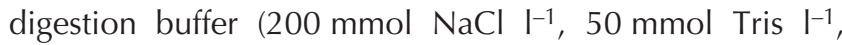
$5 \mathrm{mmol} \mathrm{CaCl} \mathrm{I}^{-1}, 1 \mu \mathrm{mol} \mathrm{ZnCl}_{2} \mathrm{I}^{-1}, 0.02 \%$ (v/v) Brij-35, pH 7.6; all chemicals from Sigma Chemical Co, St Louis, MO) for $18 \mathrm{~h}$ at $37^{\circ} \mathrm{C}$. The gels were stained in staining solution $(0.5 \%(\mathrm{w} / \mathrm{v})$ Coomassie blue R250 in 30\% (v/v) methanol$10 \%(\mathrm{v} / \mathrm{v})$ glacial acetic acid in $\mathrm{H}_{2} \mathrm{O}$ ) for $3 \mathrm{~h}$ at $23^{\circ} \mathrm{C}$, and then destained (staining solution without Coomassie blue) to reveal discrete areas in which degradation of gelatin by gelatinases is localized. A sample of human amniotic fluid collected at term during active labour was used as a positive control, which clearly demonstrated the latent forms of MMP-2 and MMP-9 as characterized by Riley et al. (1999a).

\section{Identification and measurement of TIMPs by reverse zymography}

Detection of TIMP activity was performed by reverse zymography using a commercially available kit (University Technologies Inc., Calgary) as described by Riley et al. (1999b). Follicular fluid samples (1.0-7.5 $\mu$; optimal volume established as $3 \mu \mathrm{l}$ ) were separated by PAGE using $12 \%(\mathrm{w} / \mathrm{v})$ gels containing gelatin $\left(1 \mathrm{mg} \mathrm{ml}^{-1}\right)$ and an MMP preparation (prepared from BHK-21 cells that constitutively express proMMP-2; University Technologies Inc.). Gels were washed $\left(50 \mathrm{mmol}\right.$ Tris $\mathrm{I}^{-1}, 5 \mathrm{mmol} \mathrm{CaCl}_{2} \mathrm{I}^{-1}, 2.5 \%$ (v/v) Triton $\mathrm{X}-100)$ for $2.5 \mathrm{~h}$ at $23^{\circ} \mathrm{C}$ and incubated in 
digestion buffer (50 mmol Tris ${ }^{-1}, 5$ mmol $\mathrm{CaCl}_{2} \mathrm{I}^{-1}$ ) for $17 \mathrm{~h}$ at $37^{\circ} \mathrm{C}$. The gel was counterstained and then destained (as for zymography with staining and destaining buffers) to detect the presence of protein, predominantly the incorporated gelatin. The presence of TIMPs was determined by their discrete inhibition of MMP activity, visualized as a darker band on a lighter background. TIMPs were identified and characterized by comparison with molecular mass markers, with control standards of conditioned medium containing mouse TIMP-1, -2 and -3 expressed by transfected BHK cells (University Technologies Inc.). The same human amniotic fluid control sample used in zymography was again used as a positive control (Riley et al., 1999a,b). When samples were separated by normal PAGE, without substrate or MMP activity incorporated within the gel, no detectable background protein Coomassie blue staining was observed, thus demonstrating the specificity of the TIMP activities.

\section{Localization of MMPs and TIMPs by immunohistochemistry}

MMP-1, -2 and -9, and TIMP-1, -2, -3 and -4 were localized in tissue sections ( $5 \mu \mathrm{m}$ thickness) mounted on silane-coated slides using immunohistochemical techniques as described by Riley et al. (1999b, 2000). Sections were dewaxed, rehydrated and endogenous peroxidase activity was inhibited by incubation in $\mathrm{H}_{2} \mathrm{O}_{2}(3 \%(\mathrm{v} / \mathrm{v})$ solution in $\mathrm{H}_{2} \mathrm{O}$ for $\left.20 \mathrm{~min}\right)$. Sections were washed; a blocking solution was applied (normal goat serum; $30 \mathrm{~min}$ ) followed by the primary antibody for $17 \mathrm{~h}$ at $4^{\circ} \mathrm{C}$. The following primary antibodies were used: MMP-2 (mouse monoclonal: 10-20 $\mathrm{g} \mathrm{m} \mathrm{m}^{-1} \quad$ working concentration; Calbiochem, Nottingham); MMP-9 (rabbit polyclonal: $0.1 \mu \mathrm{g} \mathrm{ml} \mathrm{m}^{-1}$; Insight Biotechnology, Wembley); TIMPs-1, -2, -3 and -4 (all rabbit polyclonal: $0.1-1.0 \mu \mathrm{g} \mathrm{ml} \mathrm{m}^{-1}$; Triple Point Biologics, Forest Grove, OR). The primary antibody was detected using a biotinylated mouse anti-horse or goat antirabbit antibody as appropriate. It was visualized using an avidin-peroxidase complex with 3,3'-diaminobenzidine as chromagen (appears brown) according to the manufacturer's instructions (Vector Laboratories, Burlingame, CA). Sections were counterstained with Harris's haematoxylin, dehydrated, mounted and visualized by light microscopy. Negative controls were performed in parallel in which the primary antibody was omitted.

\section{Data and statistical analysis}

MMP and TIMP activities as identified by zymography and reverse zymography were measured by densitometric analysis. These techniques can discriminate among different MMP and TIMP forms by molecular mass and their relative activities. Relative activity densities (expressed as arbitrary absorbance readings) were derived from zymography gels by comparison with parallel background readings of equal area and calculated using dedicated software (Quantity One; Bio-Rad). Densitometric readings were compared only with the other gel examined under exactly the same conditions (this being the same electrophoresis run and identical buffers, stains and incubation periods) as described by Riley et al. (1999b, 2000). Results were analysed using Student's $t$ test to compare between oestradiol concentrations and also densitometric values reflecting activities of different MMPs in samples collected from follicles of the same size, or ANOVA with a post hoc Tukey's test to compare activities of an MMP between follicles of different sizes.

\section{Results}

\section{Assessment of follicles}

All the follicles used in these studies were identified and classified initially as healthy or atretic according to macroscopic criteria at the time of dissection. This classification was confirmed by retrospective analysis including histological examination (data not shown). The follicles judged by histological criteria to be atretic (Kenney et al., 1979) all had high degrees of apoptosis detected by DNA laddering, whereas all follicles judged by histological examination to be healthy, had no or very low levels of DNA laddering. Furthermore, oestradiol concentrations in fluid collected from small $(<10 \mathrm{~mm}$ in diameter) follicles $\left(44.7 \pm 31.7 \mathrm{ng} \mathrm{m}^{-1}\right)$ were significantly $(P<0.01)$ lower than in the largest $(31-45 \mathrm{~mm}$ in diameter) follicles $\left(1021.2 \pm 286.8 \mathrm{ng} \mathrm{ml}^{-1}\right)$. Similarly, as a further marker for atresia, oestradiol concentrations in atretic follicles of all sizes $\left(35.8 \pm 16.0 \mathrm{ng} \mathrm{ml}^{-1}\right)$ were lower than in healthy follicles, irrespective of size.

\section{Activity of MMP-2 and MMP-9 in follicular fluid during follicular development}

In follicular fluid, the predominant gelatinase activity was present at $72 \mathrm{kDa}$, corresponding to the latent form of MMP-2, as demonstrated by zymography (Fig. 1). This finding was consistent, regardless of the stage of development of the follicle. Detection of active MMP-2 $(66 \mathrm{kDa})$ was less consistent and was detected in only four of 20 follicular fluid samples with no correlation with the stage of follicle development. Gelatinase activity was also detectable at $92 \mathrm{kDa}$, corresponding to latent MMP-9 with low amounts secreted into follicular fluid of follicles $<10 \mathrm{~mm}$ in diameter. The abundance of MMP-9 increased significantly $(P<0.05)$ in the $11-20 \mathrm{~mm}$ group when compared with the $0-10 \mathrm{~mm}$ group, and then remained at this higher level in the larger follicles. There were lower amounts of the latent forms of MMP-2 and -9 in fluid collected from atretic follicles (Fig. 2), which were remarkably consistent in samples from follicles of all sizes, although there was an increase in the amount of the active form of MMP-2 in atretic follicles. Fluid samples collected from two granulosa cell tumours also contained both MMP-2 and MMP-9 (Fig. 2). 

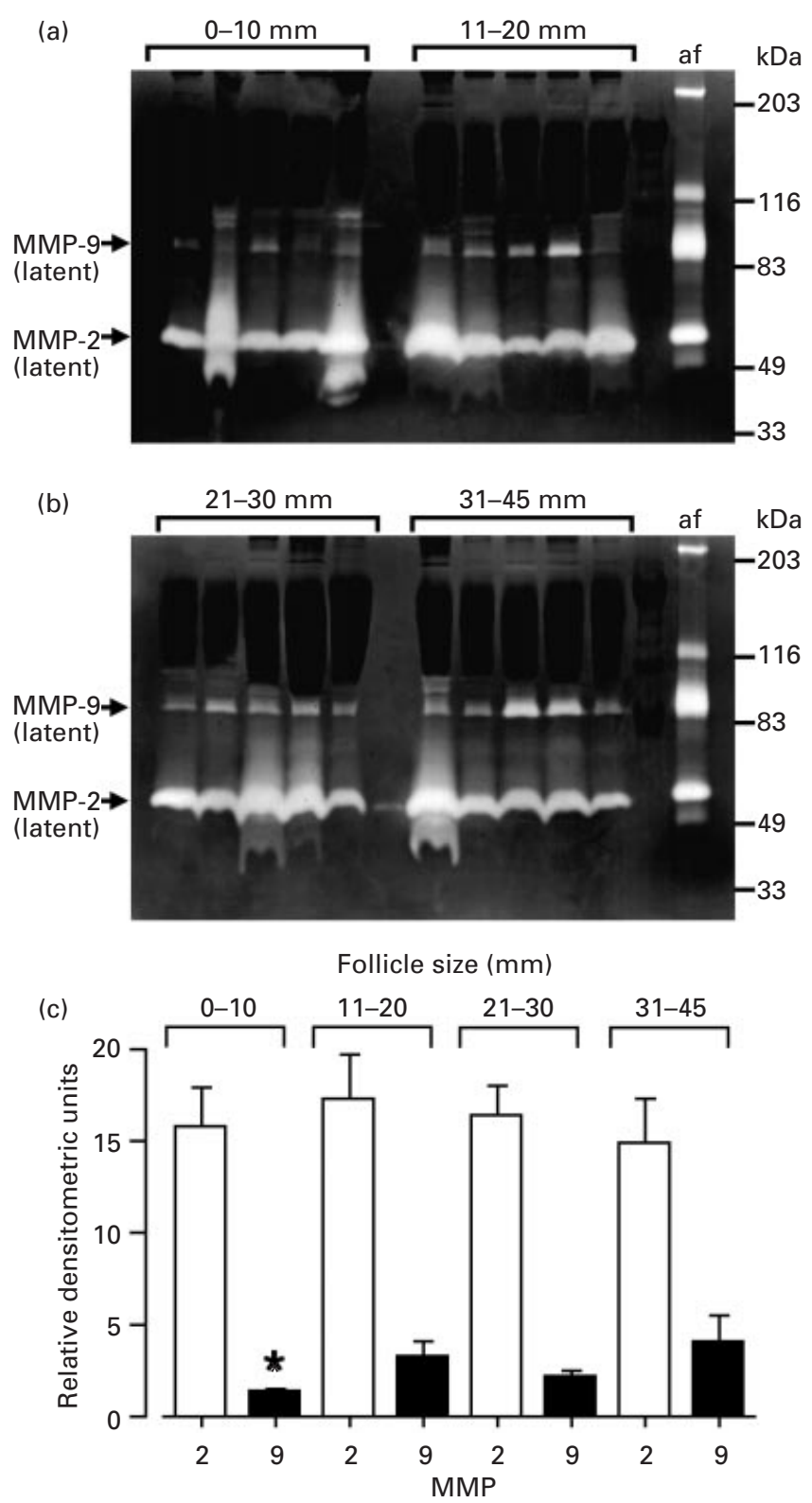

Fig. 1. (a,b) Representative gelatin zymography gels of samples of equine follicular fluid $(1.5 \mu \mathrm{l}$ analysed) from follicles in the size ranges $0-10 \mathrm{~mm}, 11-20 \mathrm{~mm}, 21-30 \mathrm{~mm}$ and $31-45 \mathrm{~mm}$ diameter. af: human amniotic fluid control sample. (c) Relative abundance (arbitrary absorbance readings; mean \pm SEM) of matrix metalloproteinase 2 (MMP-2; $\square$ ) and -9 (ם) determined by densitometric analysis. MMP-9 but not MMP-2 activity increased significantly from follicles $0-10 \mathrm{~mm}$ in diameter to follicles 21-45 mm in diameter. *Significantly $(P<0.05)$ lower MMP-9 activity compared with the larger follicle sizes.

\section{Activity of TIMPs in follicular fluid during follicular development}

A broad range of TIMP activities was detected as three bands by reverse zymography at $27-30 \mathrm{kDa}$, corresponding to the molecular mass of TIMP-1, glycosylated TIMP-3 and TIMP-4, at $24 \mathrm{kDa}$ corresponding to unglycosylated TIMP-3

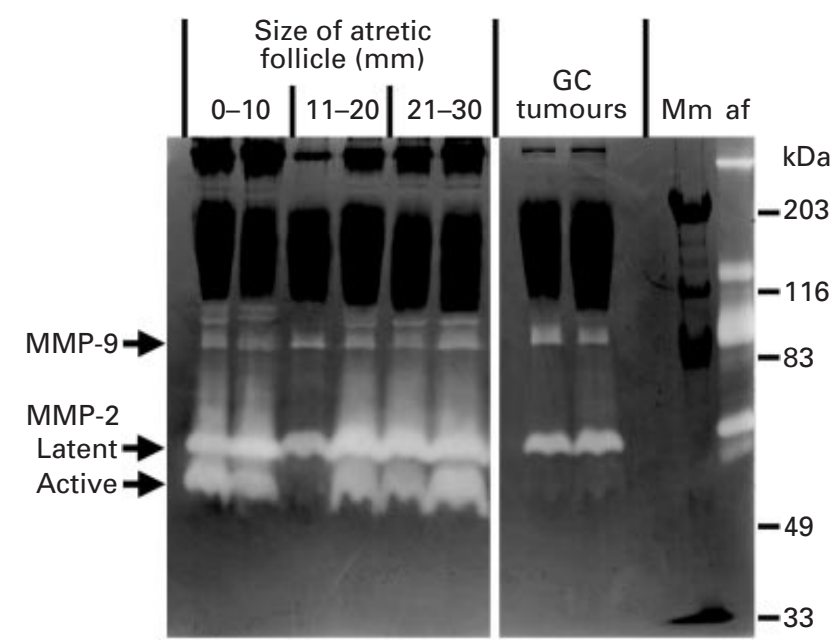

Fig. 2. Gelatin zymography gel of samples of equine follicular fluid $(5.0 \mu \mathrm{l}$ analysed) collected from atretic follicles of a range of different sizes. Samples of fluid collected from granulosa cell ovarian tumours (GC tumours) from two mares are also demonstrated. The predominant gelatinase activity detected is matrix metalloproteinase 2 (MMP-2), both latent and active forms. Mm: molecular mass markers. af: human amniotic fluid control sample.

and at $21 \mathrm{kDa}$ corresponding to TIMP-2 (Fig. 3). Reverse zymography is unable to distinguish precisely among the TIMP isoforms of 27-30 kDa molecular masses. There were no significant differences in the relative abundance of the different TIMPs during follicle development.

\section{Cellular localization of MMP-2 and -9, and TIMP-1, -2} and -4 in the follicle and ovary

Specific positive immunostaining for MMP-9 was localized consistently in theca and granulosa cell layers in follicular wall samples at stages of follicle development where follicles were $>5 \mathrm{~mm}$ in diameter (Fig. 4a). Findings were less consistent in follicles $<5 \mathrm{~mm}$ in diameter, with some positive staining in theca and granulosa layers. MMP9 was also localized in perivascular cells and weakly in the ovarian stroma, in fibroblast cells and on extracellular matrix. MMP-2 was present consistently in ovarian stroma in all samples, and in follicle tissue taken from follicles $>5 \mathrm{~mm}$ in diameter the theca and granulosa layers were consistently negative (data not shown). MMP-1 was localized predominantly in theca cells of the follicle wall only. TIMP1 (Fig. 4C), TIMP-2 (Fig. 4d) and TIMP-4 (Fig. 4f) were localized to both theca and granulosa layers at all stages of development. TIMP-3 was localized in theca cells, with little present in granulosa cells (Fig. 4e). Furthermore, all four members of the TIMP family were localized weakly to extracellular matrix and fibroblast cells in the stromal region (Fig. 4b,d,e,f), with TIMP-1, -2 and -3 being localized strongly in cells with a macrophage-like morphology (Fig. 4b,d). TIMP2 (Fig. 4d) and TIMP-3 were also present in the perivascular and smooth muscle cells surrounding the vasculature. Non- 

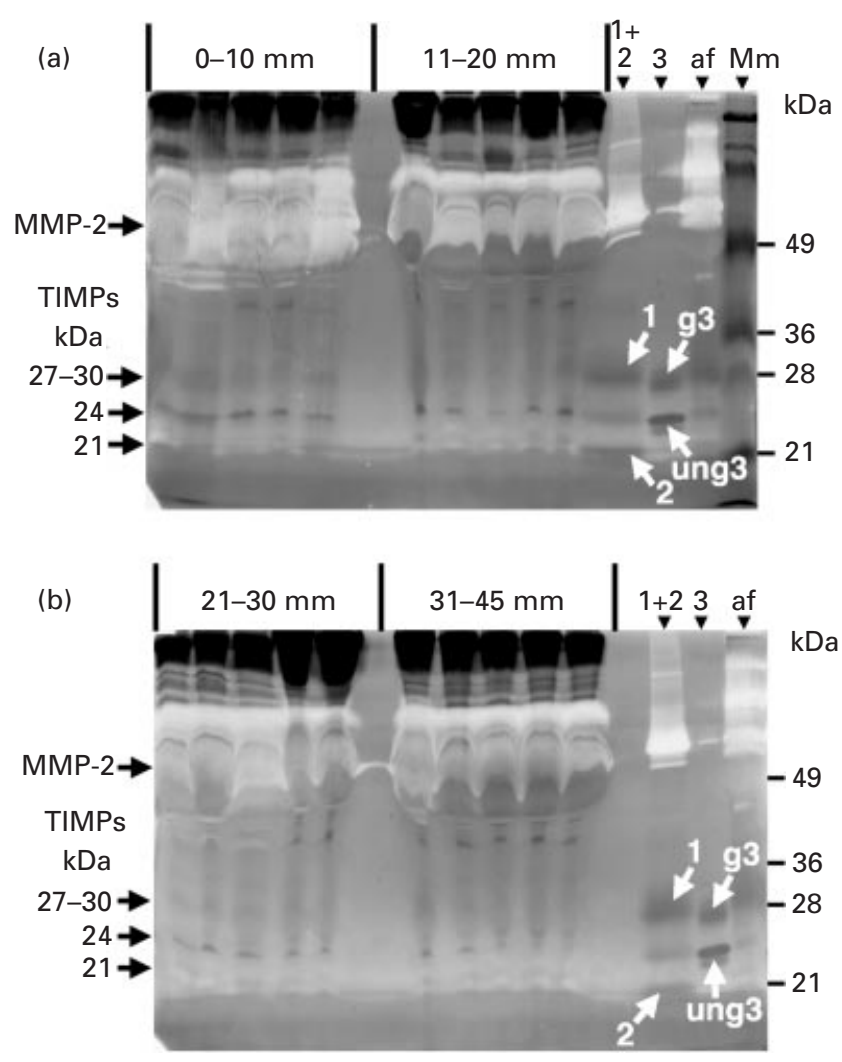

Fig. 3. Representative reverse zymography gel demonstrating tissue inhibitor of matrix metalloproteinase (TIMP) activities in mare follicular fluid samples from follicles of size ranges (a) 0-10 $\mathrm{mm}$ and $11-20 \mathrm{~mm}$ and (b) 21-30 $\mathrm{mm}$ and $31-45 \mathrm{~mm}$ in diameter. TIMP activity is visualized as three darker bands of 27-30 kDa (corresponding to the molecular masses of TIMP-1, glycosylated TIMP-3 and TIMP-4), $24 \mathrm{kDa}$ (corresponding to unglycosylated TIMP-3) and $21 \mathrm{kDa}$ (corresponding to TIMP-2). These are compared with controls (identified by arrows) for TIMP-1 and $-2(1+2)$, and TIMP-3 (3; two bands corresponding to the unglycosylated (24 kDa; ung3) and glycosylated (27 kDa; g3) isoforms) and to TIMPs in human amniotic fluid collected at term, used as a positive control (af). Mm: molecular mass markers.

specific staining was not observed in any negative control sections (for representative section see Fig. 4g).

\section{Discussion}

In the present study the presence of MMP-2 and -9 in equine follicular fluid at all stages of development has been demonstrated by gelatin substrate zymography. The most abundant gelatinase activity was due to the latent form of MMP-2 (72 kDa), which was secreted in similar amounts in all follicle sizes from $<10$ to $45 \mathrm{~mm}$ in diameter. Activity for MMP-9, although less than that of MMP-2, was also present. The concentrations of MMP-9 in follicular fluid increased significantly from the smallest follicle size $(<10 \mathrm{~mm}$ in diameter) to follicles $11-20 \mathrm{~mm}$ in diameter. A broad range of members of the TIMP family was also present in follicular fluid. These TIMP concentrations were maintained at similar values throughout follicle development. Localization of MMPs and all members of the TIMP family by immunohistochemistry revealed a complex cellular and spatial distribution. MMPs and TIMPs were localized in cells of the follicle, in the underlying stroma in several cell types including stromal fibroblasts and macrophage-like cells, cells associated with the vasculature, and also with extracellular matrix. MMP-2 was the most abundant gelatinase in fluid collected from atretic follicles and was present in both its active and latent forms, although the overall MMP-2 activity was much lower than in healthy follicles.

The presence of MMP-2 and -9 in follicular fluid, which have substrate specificities that include the basement membrane constituent collagen IV, indicates that they are likely to be required for tissue remodelling during follicle growth and development. Furthermore, the localization and secretion (Song et al., 1999) of these MMPs in cells of the ovarian stroma indicate a possible role in the migration of the follicle to the ovulation fossa. The corresponding increase in abundance of MMP-9 in larger follicles indicates strongly that MMP-9 is involved in these ovulatory processes. Ovulation is probably a result of controlled enzymatic degradation and loss of collagen in the follicle wall (Espey, 1994; Luck and Zhao, 1995), combined with local apoptosis (Murdoch, 1995) and not due to an increase of intrafollicular pressure. Collagenolytic enzymes are thought to play a vital role in ovulation in other species, including rats and macaques (Reich et al., 1985; Hirsch et al., 1993; Espey, 1994; Chaffin and Stouffer, 1999). This includes the fibrillar collagenases such as MMP-1, which break down the fibrillar collagen forms that confer much of the structural integrity to the ovarian stroma. From our studies, the possibility that there is a local and acute increase in MMPs with a concomitant decrease in TIMPs around the time of ovulation cannot be eliminated. Profound tissue remodelling occurs during the $6-12 \mathrm{~h}$ before ovulation as the follicle alters its shape from spherical to conical, directed towards the ovulatory fossa. Future studies will examine further the spatial and temporal remodelling at this time. Another candidate for the regulation of ovulation may be stimulation of MMP-2 activation, which is present in follicular fluid at all stages. MMP-2 can bind selectively to integrin $\alpha \mathrm{V} \beta 3$ (Brooks et al., 1996) to confer a specific localization and can be activated subsequently by membrane bound MMPs, including MMP-14, which are regulated by ovarian steroids (Seiki, 1999; Zhang et al., 2000), thus providing both spatial and hormone-regulated temporal control.

In the present study, a significant increase in MMP-9 concentrations in follicular fluid was observed from small $(<10 \mathrm{~mm}$ in diameter) to medium-sized $(>11 \mathrm{~mm}$ in diameter) follicles. Little is known about follicular gonadotrophin sensitivity in mares, but LH binding and mRNA encoding $\mathrm{LH}$ receptors increase in similar size ranges of follicles (> $10 \mathrm{~mm}$ in diameter) with associated increases in 

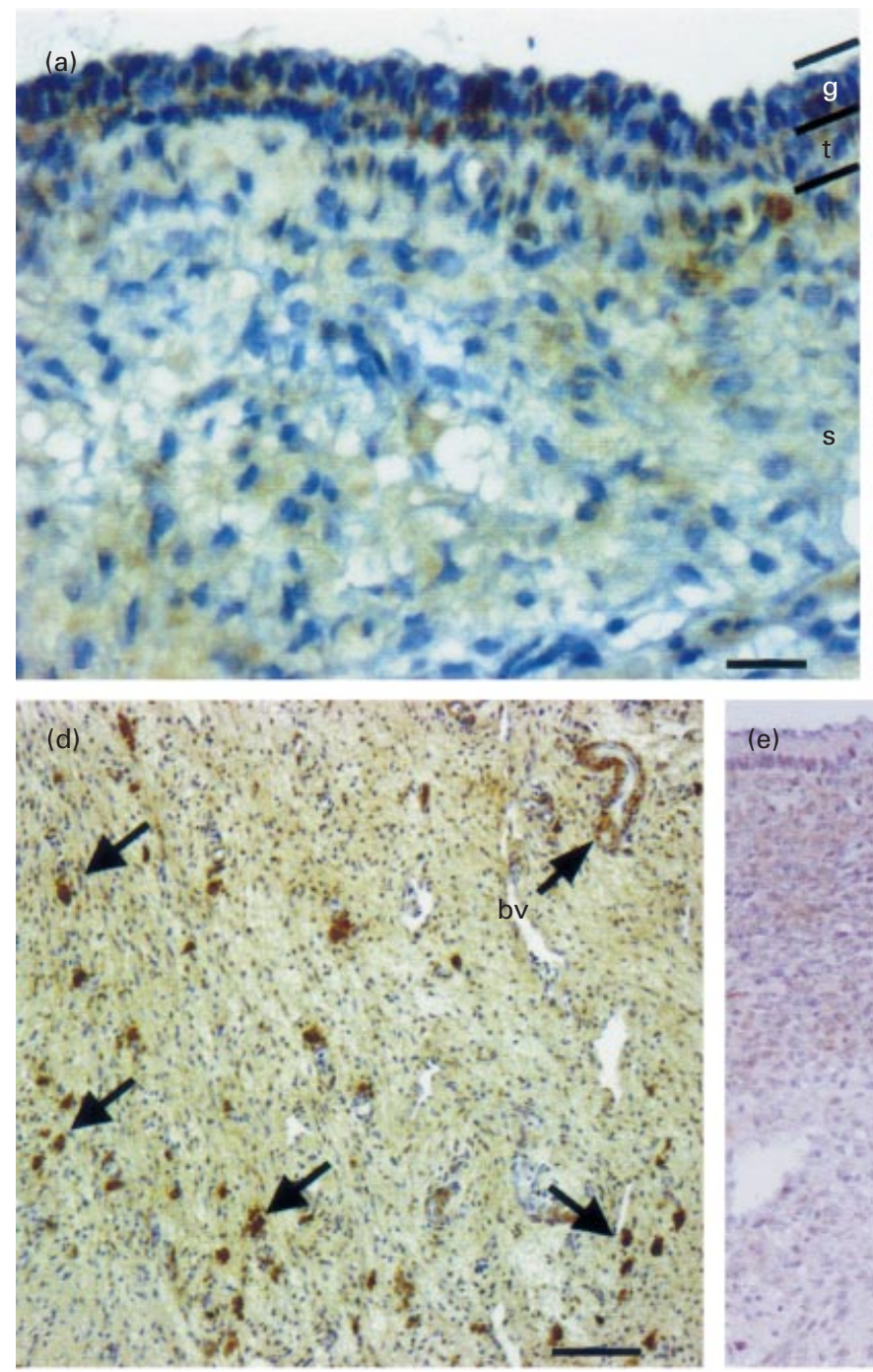

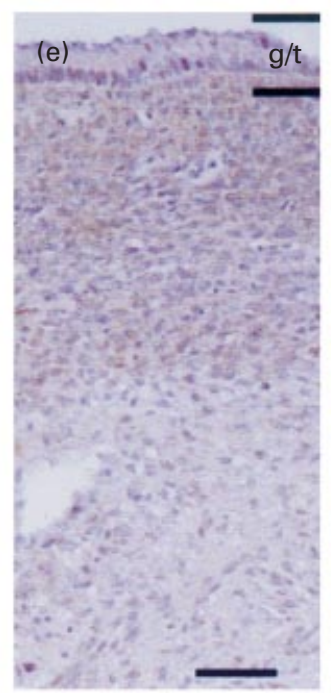

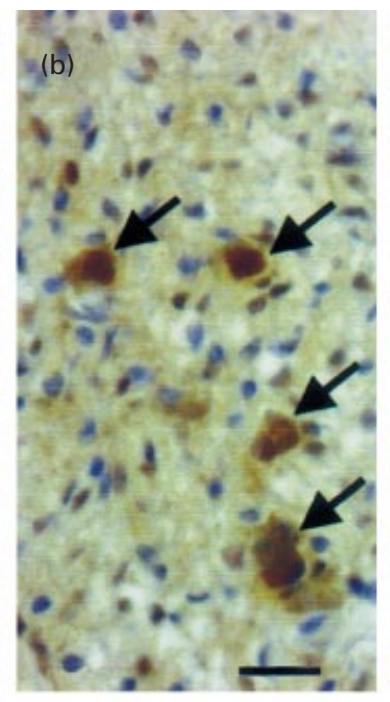
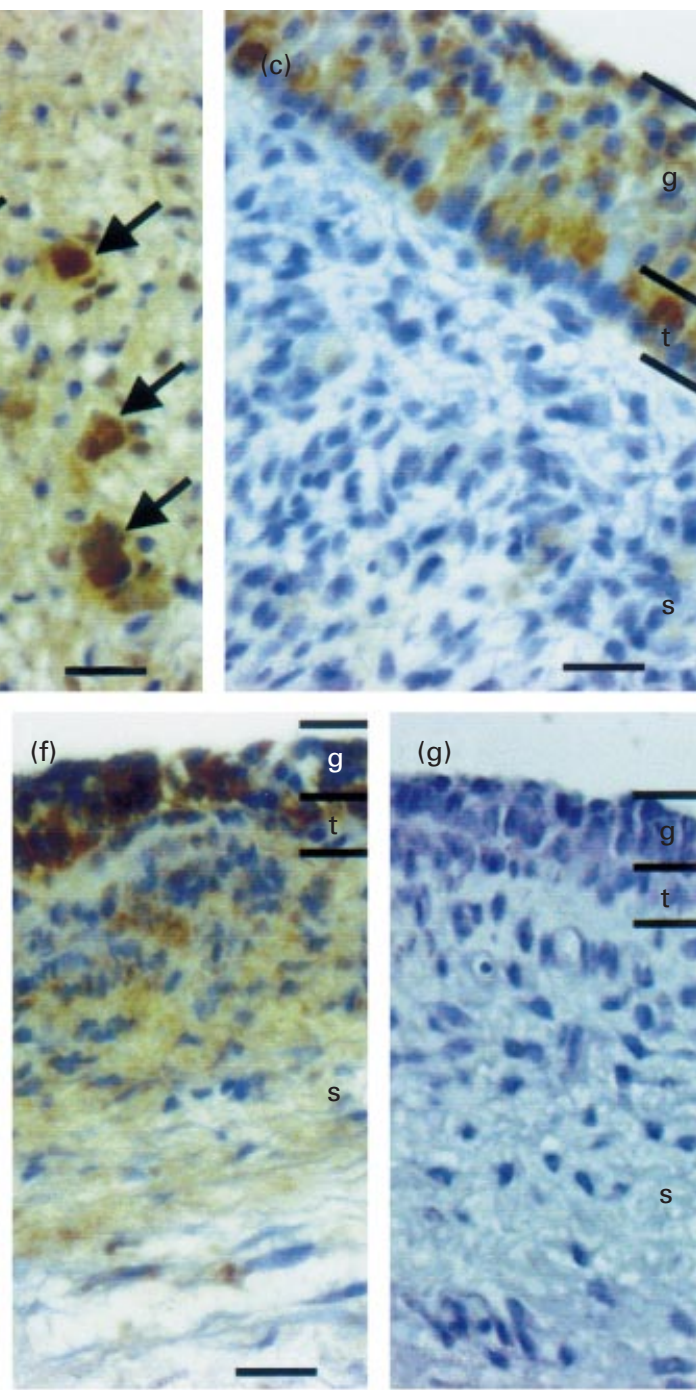

Fig. 4. Photomicrographs of representative tissue sections of equine follicles showing the localization of matrix metalloproteinase 9 (MMP9) and tissue inhibitor of matrix metalloproteinase 1 (TIMP-1), TIMP-2 and TIMP-4 by immunohistochemistry. (a) MMP-9 in granulosa and theca cells of the wall of a follicle $7 \mathrm{~mm}$ in diameter, and in underlying stromal tissue. (b) TIMP-1 in the stromal tissue in cells with macrophage-like morphology (marked by arrows). (c) TIMP-1 in granulosa and theca cells of the wall of a follicle $23 \mathrm{~mm}$ in diameter. (d) TIMP-2 in the ovarian stroma showing diffuse positive staining in fibroblast cells and extracellular matrix with some intense immunostaining in cells with macrophage-like morphology (marked by arrows), and in perivascular cells surrounding a blood vessel. (e) TIMP-3 predominantly in theca cells and stromal cells and associated with matrix underlying the theca layer. (f) TIMP-4 predominantly in the granulosa and theca cells of the wall of a follicle $23 \mathrm{~mm}$ in diameter, and in underlying stromal tissue. (g) Representative negative control section demonstrating no non-specific staining. bv: blood vessel; g: granulosa cell layer; g/t: granulosa and theca cell layers; s: stromal tissues; t: theca cell layer. Scale bars represent (a, b, c, f and g) $20 \mu \mathrm{m}$, (e) $50 \mu \mathrm{m}$ and (d) $100 \mu \mathrm{m}$.

oestrogen concentrations in follicular fluid (Fay and Douglas, 1987; Lawler et al., 1998; Goudet et al., 1999). This finding reflects an increase in aromatase activity, as androgen concentrations are high in small follicles (Fay and Douglas, 1987). Aromatase is expressed only in large (>10 mm in diameter) healthy follicles, but is absent from atretic follicles in mares (Watson and Thomson, 1996; Goudet et al., 1999).

In mares, as in other species, the presence of oestrogen in follicular fluid is thought to be anti-atretogenic (Harman et al., 1975; Kenney et al., 1979). Androgens do not appear to be associated with atresia in mares (Kenney et al., 1979; Fay and Douglas, 1987). In the present study, follicular fluid oestrogen concentrations were higher in the larger follicles classed as viable compared with follicles classed as atretic. In previous studies, there were no large differences in oestradiol concentrations in follicles $>15 \mathrm{~mm}$ in diameter, other than in those follicles classed as preovulatory (Fay and Douglas, 1987). Oestrogens may have a role in stimulating MMP-9 secretion in the larger (>10 mm in diameter) 
follicles. There were no differences in concentrations of TIMPs in follicular fluid throughout follicle development, indicating that they may be expressed constitutively.

It is becoming clear that MMPs and TIMPs have other actions on cell functions besides their role in matrix degradation. MMPs may alter local concentrations of growth factors by releasing growth factors bound to extracellular matrix during breakdown, by cleavage of prohormones, for example in the activation of tumour necrosis factor $\alpha$ (Gearing et al., 1995), or by degradation to inactive forms (Hulboy et al., 1997). Furthermore, interactions between the cell and its extracellular matrix control many functions, including the cell cycle and apoptosis, protein synthesis and invasive properties. TIMPs may also have other roles in controlling aspects of follicle development and function. TIMP-1 regulates the cell cycle and differentiation in other cell systems (Corcoran and StetlerStevenson, 1996), although it is not known whether this is mediated directly or by interactions with the extracellular matrix. Furthermore, TIMP-1 may be involved in the control of steroidogenesis, as in the testis a complex of TIMP-1 and procathepsin-L stimulates steroidogenesis (Boujrad et al., 1995). It is interesting to speculate whether the wide variety of other effects of MMPs and TIMPs mediated through cell-matrix interactions play a role in equine follicle development, selection and cellular function.

There are several possible cellular sites of secretion of MMPs and TIMPs in equine ovaries. The likely cellular sources of secretion into the follicular fluid are the granulosa, theca and interstitial cells, where MMP-2 and -9, and TIMPs, are localized by immunohistochemistry. However, this does not preclude these cells from taking up these secreted factors. These cell types have been demonstrated to express the appropriate mRNAs both in vitro and in vivo in mice, rats, cows and women, and to contain the protein and secrete these MMPs and TIMPs (Inderdeo et al., 1996; Bagavandoss, 1998; Duncan et al., 1998; Mclntush and Smith, 1998; McCaffery et al., 2000). In mares, Song et al. (1999) demonstrated that equine ovarian stromal fibroblasts secrete MMP-2 and -9 and TIMP-1, -2 and -3, as confirmed by the results of the present study. This finding is also consistent with the secretion of MMPs and TIMPs by fibroblasts derived from other tissue sources (see Hulboy et al., 1997; Nagase and Woessner, 1999). Within the ovarian stroma, we have also identified a population of cells with macrophage-like morphology that contain immunoreactivity to TIMPs and MMPs. These cells may be recruited at appropriate stages for local control of tissue remodelling, or may be resident and regulated within the ovarian stroma. MMP-2 and -9 are also secreted into cysts in granulosa cell tumours. MMPs are likely to be required for tissue remodelling during the formation of these large masses (Watson, 1999) and may be stimulated by local steroid production by the tumour.

In conclusion, the major gelatinase activity present continuously in follicular fluid is MMP-2, whereas MMP-9 activity, although in lower abundance, increases in follicular fluid during early development. A broad range of TIMPs was present in follicular fluid at all stages of development. MMP-2 and -9, and TIMPs are likely to play a role in breakdown in extracellular matrix during follicle growth and development, in follicle migration and in ovulation and in controlling other cell functions, including the cell cycle. In future studies, MMP and TIMP expression will be examined in ovarian tissue from mares in the period immediately preceding ovulation to characterize better the temporal changes involved. The roles and cellular control mechanisms of other members of the MMP family in follicle development in equine ovaries are currently under investigation.

The authors would like to thank D. R. Edwards, University of East Anglia, for supplying reagents for reverse zymography and S. G. Hillier for reagents for the oestradiol assay. A. H. Gibson was in receipt of a vacation studentship from the Faculty of Veterinary Medicine summer studentship. H. G. Pederson was in receipt of a Faculty of Veterinary Medicine PhD studentship.

\section{References}

Bagavandoss P (1998) Differential distribution of gelatinases and tissue inhibitor of metalloproteinase-1 in the rat ovary Journal of Endocrinology 158 221-228

Boujrad N, Ogwuegbu SO, Garnier M, Lee C, Martin BM and Papadopoulos V (1995) Identification of a stimulator of steroid hormone synthesis isolated from testis Science 268 1609-1612

Brooks PC, Stromblad S, Sanders LC, von Schalscha TL, Aimes RT, StetlerStevenson WG, Quigley JP and Cheresh DA (1996) Localisation of matrix metalloproteinase MMP-2 to the surface of invasive cells by interaction with integrin $\alpha v \beta 3$ Cel/ 85 683-693

Carnevale EM, McKinnon AO, Squires EL and Voss JL (1988) Ultrasonographic characteristics of the preovulatory follicle preceding and during ovulation in mares Journal of Equine Veterinary Science 8 428-431

Chaffin CL and Stouffer RL (1999) Expression of matrix metalloproteinases and their tissue inhibitor messenger nucleic acids in macaque periovulatory granulosa cells: time course and steroid regulation Biology of Reproduction 61 14-21

Corcoran ML and Stetler-Stevenson WG (1996) Tissue inhibitor of metalloproteinases-2 (TIMP-2) stimulates fibroblast proliferation via a cyclic adenosine 3',5'-monophosphate (cAMP)-dependent mechanism Journal of Biological Chemistry 27013 453-13 459

Duncan WC, McNeilly AS and Illingworth PJ (1998) The effect of luteal rescue on the expression and localisation of matrix metalloproteinases and their tissue inhibitors in the human corpus luteum Journal of Clinical Endocrinology and Metabolism 83 2470-2478

Espey LL (1994) Current status of the hypothesis that mammalian ovulation is comparable to an inflammatory reaction Biology of Reproduction $\mathbf{5 0}$ $233-238$

Fay JE and Douglas RH (1987) Changes in thecal and granulosa cell LH an FSH receptor content associated with follicular fluid and peripheral plasma gonadotrophin and steroid hormone concentrations in preovulatory follicles of mares Journal of Reproduction and Fertility Supplement 35 169-181

Gearing AJH, Beckett $\mathbf{P}$ and Christodoulow M (1995) Processing of tumor necrosis factor-alpha precursor by metalloproteinases Nature $\mathbf{3 7 0}$ $555-557$

Ginther OJ (1992) Reproductive Biology of the Mare: Basic and Applied Aspects pp 173-232. Equiservices, Cross Plains, WI

Glasier AF, Irvine DS, Wickings EJ, Hillier SG and Baird DT (1989) A comparison of the effects on follicular development between clomiphene citrate, its two separate isomers and spontaneous cycles Human Reproduction 4 252-256 
Goudet G, Belin F, Bézard J and Gérard N (1999) Intrafollicular content of luteinizing hormone receptor, $\alpha$-inhibin, and aromatase in relation to follicular growth, estrous cycle stage and oocyte competence for in vitro maturation in the mare Biology of Reproduction $601120-1127$

Hagglund A-C, Ny A, Leonardsson G and Ny T (1999) Regulation and localisation of matrix metalloproteinases and tissue inhibitors of metalloproteinases in the mouse ovary during gonadotropin-induced ovulation Endocrinology 140 4351-4358

Harman SM, Louvet JP and Ross GT (1975) Interaction of estrogen and gonadotrophins on follicular atresia Endocrinology 96 1145-1152

Harrison RJ (1946) The early development of the corpus luteum in the mare Journal of Anatomy $\mathbf{8 0} 160-166$

Hirsch B, Leonhardt S, Jarry H, Reich R, Tsafriri A and Wuttke W (1993) In vivo measurement of rat ovarian collagenolytic activities Endocrinology $1332761-2765$

Hulboy DL, Rudolph LA and Matrisian LM (1997) Matrix metalloproteinases as mediators of reproductive function Molecular Human Reproduction 3 27-45

Inderdeo DS, Edwards DR, Han VKM and Khokha R (1996) Temporal and spatial expression of tissue inhibitors of metalloproteinases during the natural ovulatory cycle of the mouse Biology of Reproduction $\mathbf{5 5}$ 498-508

Kenney RM, Condon W, Ganjam VK and Channing C (1979) Morphological and biochemical correlates of equine ovarian follicles as a function of their state of viability or atresia Journal of Reproduction and Fertility Supplement 27 163-171

Lawler DF, Armstrong DG, Baxter G, Hogg C and Watson ED (1998) Localisation of mRNA encoding luteinising hormone receptor in the equine follicle and corpus luteum Proceedings of the 7th International Symposium in Equine Reproduction, Pretoria 57-58

Luck MR and Zhao Y (1995) Structural remodelling of reproductive tissues Journal of Endocrinology 146 191-195

McCaffery FH, Leask R, Riley SC and Telfer EE (2000) Culture of bovine preantral follicles in a serum-free system: markers for assessment of growth and development Biology of Reproduction 63 267-273

McIntush EW and Smith MF (1998) Matrix metalloproteinases and tissue inhibitors of metalloproteinases in ovarian function Reviews of Reproduction 3 23-30

Murdoch WJ (1995) Programmed cell death in preovulatory ovine follicles Biology of Reproduction 53 8-12

Murdoch WJ and McCormick RJ (1992) Enhanced degradation of collagen within apical vs basal wall of ovulatory ovine follicles American Journal of Physiology $263221-225$

Nagase H and Woessner JF (1999) Matrix metalloproteinases Journal of Biological Chemistry $27421491-21494$

Pedersen HG (2000) Follicular Growth and Regression in the Mare PhD Thesis, University of Edinburgh

Pedersen HG, Watson ED and Telfer EE (2000) Apoptosis in equine granulosa cells and its relationship to cumulus expansion and oocyte chromatin configuration in ovarian follicles Journal of Reproduction and Fertility Supplement 56 455-462

Pierson RA and Ginther OJ (1985) Ultrasonic evaluation of the preovulatory follicle in the mare Theriogenology 24 359-368

Prickett ME (1966) Pathology of the equine ovary Proceedings of the
Annual Convention of the American Association of Equine Practitioners, Los Angeles 145-153

Rawdanowicz TJ, Hampton AL, Nagase H, Woolley DE and Salamonsen LA (1994) Matrix metalloproteinase production by cultured human endometrial stromal cells: identification of interstitial collagenase, gelatinase-A, gelatinase-B, and stromelysin-1, and their differential regulation by interleukin- $\alpha$ and tumor necrosis factor- $\alpha$ Journal of Clinical Endocrinology and Metabolism 79 530-536

Reich R, Tsafriri A and Mechanic GL (1985) The involvement of collagenolysis in ovulation in the rat Endocrinology 116 522-527

Riley SC, Leask R, Chard T, Wathen NC, Calder AA and Howe DC (1999a) Secretion of matrix metalloproteinase-2, matrix metalloproteinase- 9 and tissue inhibitor of metalloproteinases in the intrauterine compartments during early pregnancy Molecular Human Reproduction 5 376-381

Riley SC, Leask R, Denison FC, Wisely K, Calder AA and Howe DC (1999b) Secretion of tissue inhibitors of metalloproteinases by human fetal membranes, decidua and placenta at parturition Journal of Endocrinology 162 351-359

Riley SC, Webb CJ, Leask R, McCaig FM and Howe DC (2000) Involvement of matrix metalloproteinases-2 and -9, tissue inhibitor of metalloproteinases and apoptosis in tissue remodelling in the sheep placenta Journal of Reproduction and Fertility 118 19-27

Seiki M (1999) Membrane-type matrix metalloproteinases APMIS 107 137-143

Smith GW, Juengel JL, McIntush EW, Youngquist RS, Garverick HA and Smith MF (1996) Ontogenies of messenger ribonucleic acid encoding tissue inhibitor of metalloproteinases 1 and 2 within bovine periovulatory follicles and luteal tissue Domestic Animal Endocrinology 13 151-160

Song L, Porter DG and Coomber BL (1999) Production of gelatinases and tissue inhibitors of matrix metalloproteinases by equine ovarian stromal cells in vitro. Biology of Reproduction $601-7$

Watson ED (1999) Granulosa cell tumours in the mare: a review of nine cases Equine Veterinary Education 11 16-142

Watson ED and Sertich PL (1990) Secretion of prostaglandins and progesterone by cells from corpora lutea of mares Journal of Reproduction and Fertility 88 223-229

Watson ED and Thomson SRM (1996) Immunohistological localisation of P-450arom within the ovaries of pregnant and nonpregnant mares Journal of Reproduction and Fertility 108 239-244

Witherspoon DM and Talbot RB (1970) Ovulation site in the mare Journal of the American Veterinary Medical Association 157 1452-1459

Woessner JF (1991) Matrix metalloproteinases and their inhibitors in connective tissue remodelling FASEB Journal 5 2145-2154

Zhang J, Hampton LA, Nie AG and Salamonsen LA (2000) Progesterone inhibits activation of latent matrix metalloproteinase (MMP)-2 by membrane type $1 \mathrm{MMP}$ : enzymes co-ordinately expressed in human endometrium Biology of Reproduction 62 85-94

Received 25 September 2000.

First decision 2 November 2000

Accepted 22 November 2000. 